\title{
OESTRUS AND OVARIAN HISTOLOGY IN THE LACTATING VOLE (MICROTUS AGRESTIS)
}

\author{
W. G. BREED* \\ Department of Agriculture, Oxford University \\ (Received 1st February 1968, revised 28th May 1968)
}

\begin{abstract}
Summary. Lactation lasts for about 14 days in the field vole. Early in lactation the corpora lutea were large although some signs of degeneration were present; by Day 13 none could be recognized. Graafian follicles were present throughout the period but were slightly reduced in size during mid-lactation.

Vaginal smear patterns varied considerably between individuals although nucleated epithelial cells usually predominated.

Mating tests were carried out between Days 2 and 13 of lactation. $81 \%$ proved successful; coitus occurred on all days. $59 \%$ of the matings resulted in pregnancies that were carried to term. No reduction of litter size was apparent as a result of these matings. Gestation length was slightly prolonged when more young were being suckled. Most matings took place when there was a predominantly nucleated epithelial smear.

It is concluded that, in this stock, the only corpora lutea present during lactation are those of the previous pregnancy. The presence of Graafian follicles suggests that suckling does not entirely inhibit FSH secretion although the decrease in follicular size in mid-lactation may indicate slight FsH reduction. There were no 3- to 4-day oestrous cycles. The occurrence of mating and the predominant type of vaginal smear suggests continuous secretion of oestrogen. This may partly explain the lack of a marked implantation delay during lactation. There appears to be no inhibition of release of ovulatory-inducing hormone due to suckling nor of ovulation and resulting gestation even though the Graafian follicles are slightly reduced.
\end{abstract}

\section{INTRODUCTION}

In wild short-tailed field voles (Microtus agrestis), Brambell \& Hall (1939) considered that if post partum mating did not occur lactation anoestrus set in, the corpora lutea formed at post partum heat becoming the corpora lutea of lactation, Leslie \& Ranson (1940) found that the average intervals between pregnancies in a laboratory stock was 30 days. Since the gestation length was 21 days they suspected that one or possibly two ovulations took place during the fortnight of lactation. Chitty (1957) quoted later unpublished data of Leslie and Ranson

\footnotetext{
* Present address: Department of Anatomy, Medical School, University of California, Los Angeles 90024.
} 
which was considered suggestive of a 7- to 8-day oestrous cycle during lactation, although vaginal smears, taken by Chitty, indicated a 3- to 4-day cycle which was "much like" that of Peromyscus maniculatus (Glark, 1936). Chitty also found that coitus occurred at the 3- to 4-day oestrous peaks. She suggested that the discrepancy between her results and those of Leslie and Ranson might be due to the improved management of animals. As Chitty states that mammals with short oestrous cycles usually ovulate spontaneously, it is implied that this took place every 3 to 4 days during lactation in this species.

Since most rodents and rabbits have a lactation anoestrus, and as the virgin vole has been shown to be an induced ovulator (Austin, 1957; Breed, 1967; Clarke \& Kennedy, 1967), a re-investigation of the lactating vole seemed highly desirable.

\section{MATERIALS AND METHODS}

The animals were from the same stock as that used by Clarke \& Kennedy (1967). They were kept at 18 to $21^{\circ} \mathrm{G}$ and on a 16-hr light/8-hr dark regime. Unrationed oats, hay and water were provided and fresh carrot twice weekly. Some individuals were also supplied with a supplementary Oxoid Breeding Diet.

\section{Ovarian histology}

Lactation does not normally last longer than 14 days (see Ranson, 1934). Four primiparous females were killed every 3rd day of lactation (Day 1 being taken as the day on which the young were first found). The ovaries were fixed in Bouin's fixative, weighed and embedded in paraffin wax. They were serially sectioned at $7 \mu$ and stained with Ehrlich's haematoxylin and eosin.

The diameter of every corpus luteum (CL) was calculated from measurements of two axes at right angles through the centre of the largest section and the mean diameter of all cL in every animal was obtained. Vesicular follicles were measured similarly. The number and mean diameters were recorded of those greater than $400 \mu$, since these had well-developed antra and hence were classified as Graafian follicles (GF). They were also allotted to size categories as shown in Table 1. Vesicular follicles undergoing atresia (AF) were counted.

\section{Vaginal smears}

Smears were taken twice daily with a platinum loop at 10.00 and 19.00 hours and before a mating test. They were air-dried and stained by the method of Papanicolaou (1954). Only those taken for 5 or more days from parturition were analysed. The abundance of leucocytes, nucleated epithelial and cornified cells was estimated for each smear.

\section{Mating tests}

Sexual receptivity was tested in lactating females which had been isolated from their mates in late pregnancy. Females were removed from their litters and placed in mating cages $(28 \times 18 \times 12 \mathrm{~cm})$. A fertile male was immediately introduced to each cage. If sexual interest was shown, the pair was left together 


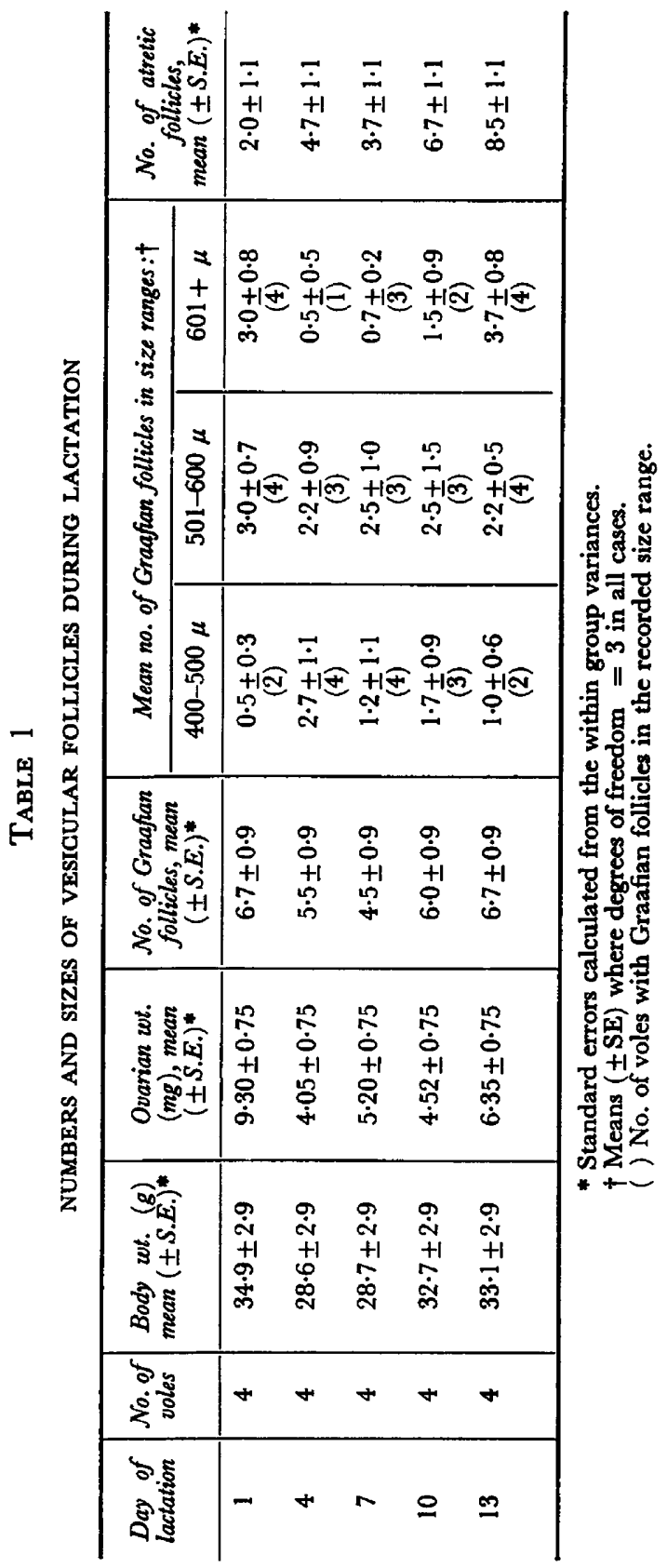


for up to $2 \mathrm{hr}$. In a few cases, up to four males were tested with one female. Mating was considered successful if mounting, followed by pelvic thrusts and/ or the presence of a vaginal plug, was observed. The females were returned to their litters at the end of the tests, the young being removed when 18 days old. The mother's cage was then inspected daily for the presence of a subsequent litter.

\section{RESULTS}

\section{Ovarian weights}

An analysis of variance demonstrated significant differences between ovarian weights for different times during lactation $(\mathrm{F}=6.87 ; P<0.01)$ although body weights did not differ significantly. Table 1 shows that a marked reduction in ovarian weight occurred between Days 1 and 4 .

\section{Ovarian histology}

Corpora lutea. Text-figure 1 shows that the mean size of the CL became greatly reduced during lactation and were unrecognizable by Day 13 (see Plate 1 ).

On Day 1, all CL in any one female were similar histologically but some variation was found between animals. In two females, in which the mean CL diameters exceeded $800 \mu$, most of the luteal cells were large with eosinophilic cytoplasm and vesicular nuclei although a few pycnotic nuclei were also present (Pl. 2, Fig. 1). Estimated CL diameters for the other two females were $644 \pm 36 \mu$ and $642 \pm 65 \mu$. The cytoplasm was also eosinophilic, but it often appeared to have contracted somewhat and the nuclei were mostly pycnotic (Pl. 2, Fig. 2).

Females killed on Day 4 had cL with well-spaced nuclei (Pl. 1, Fig. 2 and Pl. 2, Fig. 3). In different individuals these were either predominantly vesicular or pycnotic. Usually the nuclei tended to vary considerably in size and shape. The cytoplasm was only slightly eosinophilic (Pl. 2, Fig. 3). No leucocytic invasion was evident, although blood vessels were often prominent. Females killed on Days 7 and $10 \mathrm{had}$ CL in which a large proportion of nuclei were pycnotic, and the cytoplasm tended to be vacuolated (Pl. 2, Fig. 4). By Day 13 CL could not be identified. Hence no recently formed CL were found during lactation in any of the ovaries.

\section{Graafian follicles}

There were no significant differences between numbers of GF for different periods during lactation (analysis of variance: $F=1.0 ; P>0.05$ ) (see Table 1 ). However, Text-fig. 1 suggests that during mid-suckling the mean GF size is reduced and greater variability between individuals occurred. An analysis of variance demonstrated that differences between the 3-day periods was on the borderline of significance $(\mathbf{F}=2.43 ; P<0 \cdot 1>0 \cdot 05)$. Graafian follicle size distribution was, therefore, investigated in more detail by allotting the GF to size categories and comparing the mean number in each for different times during lactation (Table 1). After pooling the data for Day 1 (when suckling is not likely to have had time to induce an effect) and Day 13 (when the intensity of 
PL.ATE I

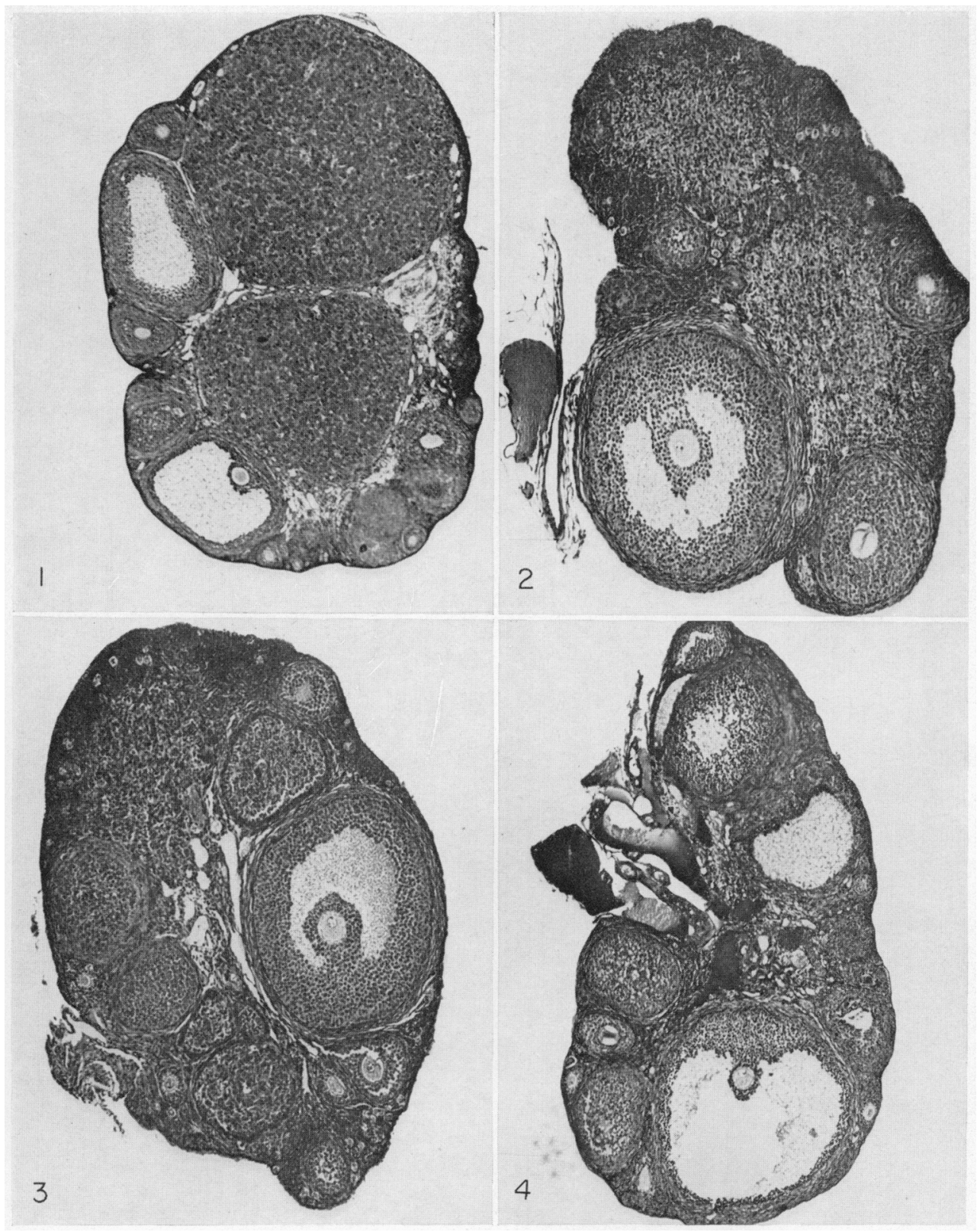

Ovarian morpholog: during lactation. Note lack of much interstitial tissue in all ovaries.

Fí. 1. Female vole killed on Day 1. Large cu present. $\times 40$.

Fis: 2. Fernale killed on Day 4. (a, smaller with woll-spaced nuclei. $A$ ciF is also present. $\times 40$.

Fis. 3. Female killed on 1)ay 7. (is degenerating (top left). One (ar present. $\times 80$.

II 4 . 4. Female killed on Day 10. A large $\mathrm{sF}$ present. No ci visible. $\times 60$. 


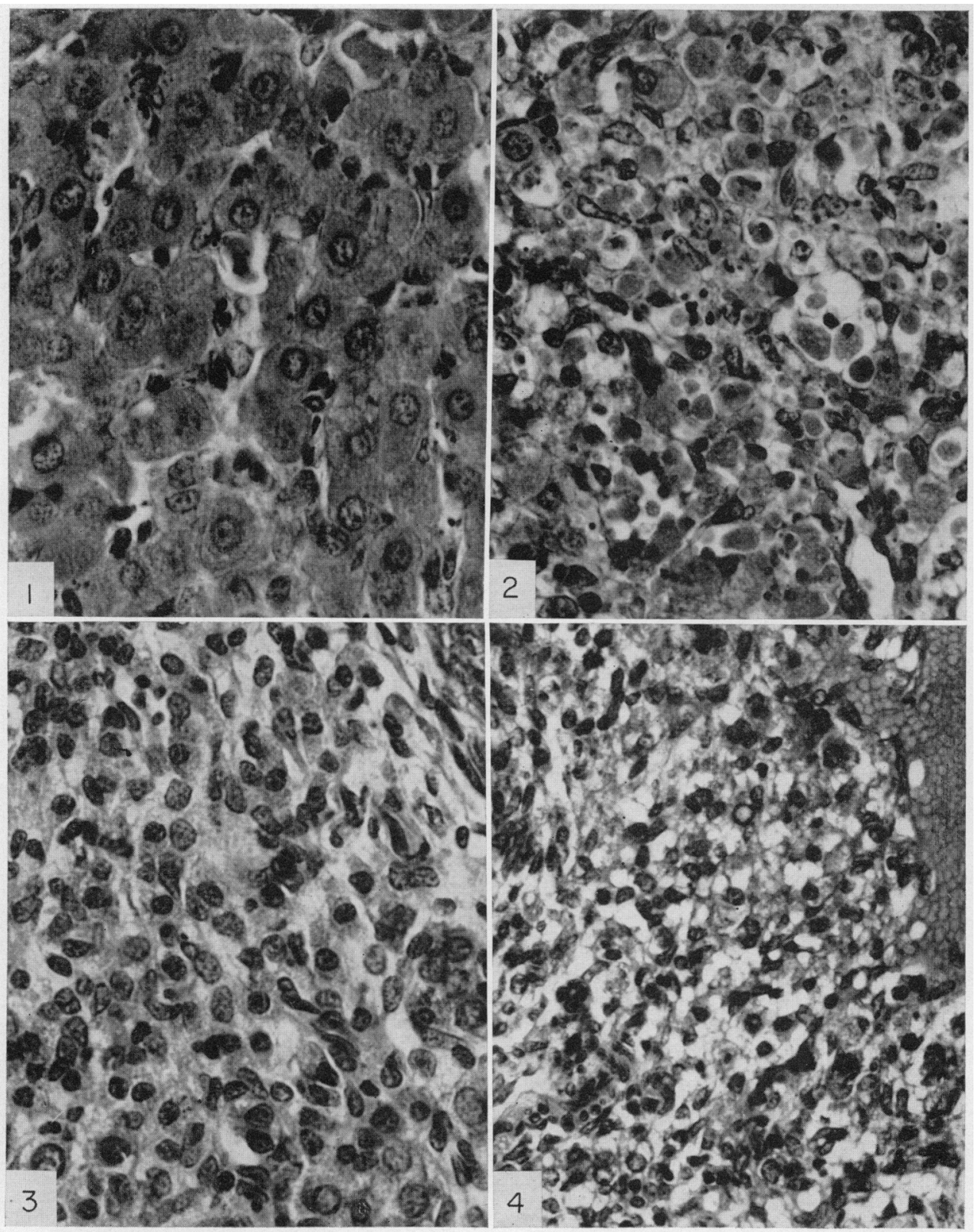

I.uteal cell histologs.

Fo. I. Fenale killed on Day I. ci. size greater than $800 \mu$. Sost luteal colls large with vesicular nuclei. Cytoplasm cosinophilic $\times 640$.

Fics.2. Female killed on Day l. cis size less than $800 \mu$. Majorityofluteal cell nuclei pyknotic. Cytoplasm appears to have contracted. $\times 640$.

Fio. 3. Female killed on 1)ay 4 . Nuclei predominantl wesiculat but irregular in shape. Cytoplasm weakly eosinophitic $\times 640$.

Fics. 4. Fenale killed on 1)ay 10. Nuclei well spaced and variable in size and shape. (ivtoplasm racuolated. $\times 6+0$. 
suckling, and hence its effect, has been considerably reduced) and comparing it to the pooled data for the mid-suckling period (Days 4, 7 and 10) considerably more GF greater than $601 \mu$ were shown to occur on Days 1 and $13(t=3.98$; $P<0.001)$. Moreover, the proportion of females on Days 1 and 13 with GF more than $601 \mu$ was significantly greater than during the intermediate period $(\chi=5.71 ; P<0.05)$. Hence it appears that during mid-suckling GF are inhibited from attaining their normal maximum size.

Table 1 also shows that there is an increase in number of $\mathrm{AF}$ as suckling progresses. An analysis of variance showed that this increase was significant $(\mathrm{F}=4.88 ; P<0.01)$.

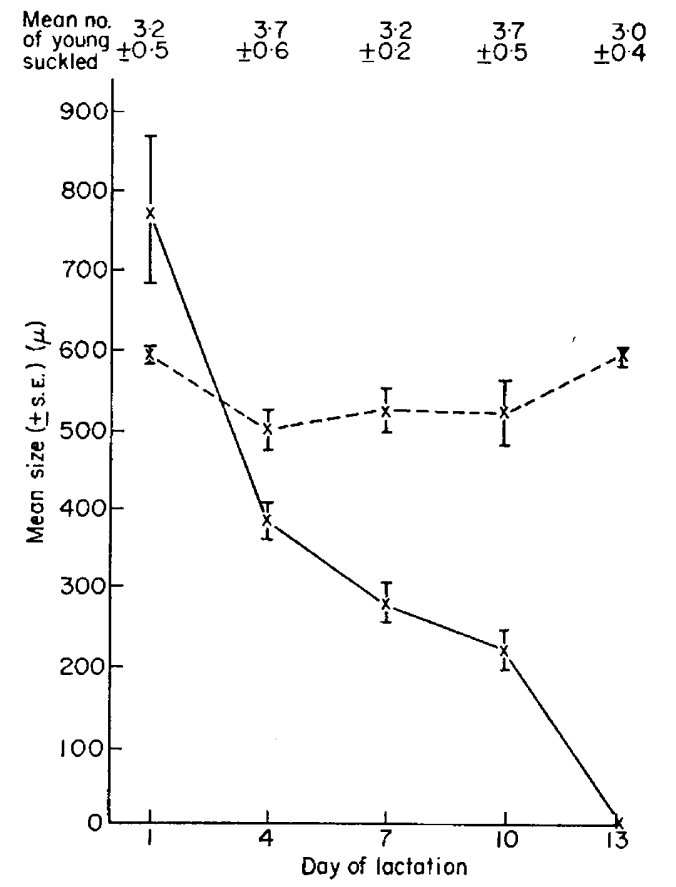

Text-Fig. 1. Mean size ( \pm S.E.) of corpora lutea $(-\longrightarrow$ ) and Graafian follicles $(---)$. Each group contained four animals.

Vaginal smear changes during lactation

The analysis of thirty-one smear patterns is given below. For the first 2 to 3 days the smears were thin, after which the following patterns emerged:

1. A predominantly nucleated smear with other cells present (nine animals).

2. A nucleated smear with periodic cornification (three animals).

3. A nucleated smear with at least one leucocytic invasion (three animals).

4. A nucleated smear with occasional invasions of cornified cells and leucocytes; a marked drop in abundance of nucleated cells often coincided with peaks of cornification (eight animals).

5. Continuous cornification (three animals).

6. Cornification with periodic invasions of leucocytes and nucleated cells (three animals).

7. A thin smear with occasional leucocytic invasions (two animals). 
No relationship occurred between the smear pattern and the number of young suckled, nor was there any indication of a 3- to 4-day cycle.

Vaginal smears at time of mating test

Smears taken just before thirty-two successful mating tests revealed predominantly nucleated epithelial cells in twenty-five individuals; five of these contained some leucocytes. Cornified cells were most abundant in only four animals. In two voles, smears were thin and contained mucus. In a third that mated on Day 2, the smear was leucocytic. Five of the seven smears recorded before unsuccessful mating tests were mainly cornified, one was thin and the other leucocytic.

\section{Mating tests}

Table 2 shows that mating took place on all days between 2 and 13 of lactation. Thirty-nine of the forty-eight tests were successful. Only two females

TABLE 2

MATING TESTS DURING LACTATION

\begin{tabular}{c|c|c|c}
\hline $\begin{array}{c}\text { Day of } \\
\text { lactation }\end{array}$ & $\begin{array}{c}\text { No. of } \\
\text { females tested }\end{array}$ & $\begin{array}{c}\text { No. of } \\
\text { successful } \\
\text { mating tests }\end{array}$ & $\begin{array}{c}\text { No. of young } \\
\text { suckled by females } \\
\text { that mated, mean } \\
( \pm S . E .)\end{array}$ \\
\hline 2 & 3 & 3 & $4 \cdot 7 \pm 1 \cdot 2$ \\
3 & 3 & 3 & $5 \cdot 0 \pm 0$ \\
4 & 3 & 3 & $5 \cdot 3 \pm 1 \cdot 5$ \\
5 & 4 & 4 & $5 \cdot 5 \pm 1 \cdot 0$ \\
6 & 4 & 3 & $4 \cdot 0 \pm 1 \cdot 1$ \\
7 & 6 & 5 & $5 \cdot 0 \pm 0.7$ \\
8 & 4 & 3 & $2 \cdot 7 \pm 0.7$ \\
9 & 4 & 3 & $5 \cdot 0 \pm 1 \cdot 1$ \\
10 & 5 & 3 & $4 \cdot 0 \pm 0.6$ \\
11 & 5 & 3 & $5 \cdot 3 \pm 0.9$ \\
12 & 4 & 3 & $4 \cdot 3 \pm 1 \cdot 3$ \\
13 & 3 & 3 & $5 \cdot 3 \pm 1 \cdot 7$ \\
Total & 48 & 39 & $4 \cdot 7 \pm 0.2 *$ \\
\hline
\end{tabular}

did not copulate (one was tested on 3 , and the other on 2 different days). Three others did not mate on the first day of testing, but did so subsequently. Coitus usually occurred within a few minutes. Mounting was usually seen and vaginal plugs were found in thirty-seven animals. The mean number $( \pm$ S.E. $)$ of young suckled by the thirty-nine females that mated was $4 \cdot 7 \pm 0 \cdot 2$.

Twenty-three of the thirty-nine matings resulted in the birth of young 20 to 23 days later (Table 3 ); the mean litter size was $5 \cdot 1 \pm 0 \cdot 3$. This was not significantly different from that of the previous mean litter size of the same animals $(4 \cdot 8 \pm 0 \cdot 3)$. Table 3 also demonstrates that the number of young suckled does not affect the chance of the pregnancy being carried to term. Vaginal smears and/or body weight changes subsequent to mating indicated that six of the sixteen females that failed to give birth to live young probably became pregnant 
or pseudopregnant. These mated on Days 2 (one), 5 (one), 6 (one), 8 (one) and 9 (two) post partum. One female, as judged by the smear after mating, did not ovulate on Day 7. No relevant data were obtained from the other nine females. The mean length of gestation was $20.7 \pm 0.3$ days. Regression analysis showed that there was a statistically significant increase in gestation length when more young were suckled; $r=19 \cdot 67+0 \cdot 24 X$, where $Y=$ length of pregnancy and $X$ $=$ number of young suckled $(\mathrm{t}=2.4 ; P<0.05)$. No relationship was found between the time during lactation at which mating took place and the resulting length of gestation.

\section{TABLE 3}

NUMBER OF PREGNANCIES CARRIED TO TERM

\begin{tabular}{|c|c|c|c|c|}
\hline \multirow{2}{*}{$\begin{array}{l}\text { Day of } \\
\text { lactation }\end{array}$} & \multirow{2}{*}{$\begin{array}{c}\text { No. of } \\
\text { females mated }\end{array}$} & \multirow{2}{*}{$\begin{array}{l}\text { No. of } \\
\text { females that } \\
\text { carried } \\
\text { pregnancy to } \\
\text { term }\end{array}$} & \multicolumn{2}{|c|}{ No. of young suckled when: } \\
\hline & & & $\begin{array}{c}\text { Pregnancy carried } \\
\text { to term }\end{array}$ & $\begin{array}{l}\text { Pregnancy not } \\
\text { carried to term }\end{array}$ \\
\hline $\begin{array}{r}2 \\
3 \\
4 \\
5 \\
6 \\
7 \\
8 \\
9 \\
10 \\
11 \\
12 \\
13\end{array}$ & $\begin{array}{l}3 \\
3 \\
3 \\
4 \\
3 \\
5 \\
3 \\
3 \\
3 \\
3 \\
3 \\
3\end{array}$ & $\begin{array}{l}2 \\
3 \\
3 \\
2 \\
2 \\
3 \\
2 \\
0 \\
1 \\
1 \\
2 \\
2\end{array}$ & $\begin{array}{l}5 ; 5 \\
5 ; 5 ; 5 \\
3 ; 5 ; 8 \\
4 ; 6 \\
2 ; 6 \\
3 ; 4 ; 7 \\
2 ; 4 \\
4 \\
6 \\
3 ; 6 \\
3 ; 6\end{array}$ & $\begin{array}{l}\frac{5}{7} \\
\overline{4} ; 8 \\
4 \\
5 ; 6 \\
2 ; 5 ; 7 \\
3 ; 5 ; 7 \\
3 ; 5 \\
4 ; 6 \\
3 \\
7\end{array}$ \\
\hline Total & 39 & 23 & $\begin{array}{l}* \bar{x}( \pm \text { S.E. }) \\
4.7 \pm 0 \cdot 3\end{array}$ & $\begin{array}{l}* \bar{x}( \pm \text { S.E. }) \\
4.9 \pm 0.4\end{array}$ \\
\hline
\end{tabular}

* Mean ( \pm S.E.) of all observations.

\section{DISCUSSION}

The results conflict with the conclusions from the field data of Brambell \& Hall (1939), and with those of Chitty (1957). There was no spontaneous ovulation post partum and thus no cL of lactation, nor did spontaneous ovulation occur during lactation. The cL present declined markedly in size during lactation and could not be seen by Day 13; the two females with smaller cL on Day 1 had probably been killed at a longer time after parturition. Decline in CL size no doubt accounted for the reduction in ovarian weight. Vaginal smear patterns showed no indication of a 3- to 4-day cycle. Nucleated epithelial cells usually predominated but the patterns varied much between individuals. There was no lactation anoestrus, nor was receptivity restricted to 3- to 4-day periods. Mating occurred on all days. Most females mated on the lst day of testing, the majority of which ovulated and carried pregnancies to term. The failure of a few females to mate could have been due to lack of receptivity, lack of motivation in the male or behavioural incompatibility between the pair.

Differences between the smear patterns recorded by Chitty and those obtained in the present study are difficult to explain. Her animals, although kept 
on a 16-hr lighting regime, were fed on a somewhat different diet $(\mathrm{H}$. Chitty, personal communication). Such factors cannot be excluded from influencing ovarian function. Chitty only carried out mating tests at the 3- to 4-day periods of oestrus; hence no evidence of lack of a 3- to 4-day cycle of sexual receptiveness was obtained. Her evidence for lack of a markedly lengthened gestation period was verified.

A 12- to 14-day suckling period, and gestation of normal length during suckling, occurs in $M$. pennsylvanicus (Bailey, 1924; Hamilton, 1941), M. californicus (Selye, 1928; Greenwald, 1957) and M. oregoni (Cowan \& Arsenault, 1954). Five microtine species have been shown to have a post partum heat (Asdell, 1964). In M. pennsylvanicus, Hamilton (1941) considered that an oestrous cycle followed immediatelyafter parturition and some individuals conceived 5 or 6 days post partum. Greenwald (1956) caught wild lactating $M$. californicus that had corpora albicantia but no corpora lutea. As lactating voles were also obtained that had recently formed CL, he suggested that oestrus might occur in the early stages of lactation; there was no spontaneous ovulation post partum.

Spontaneous ovulation occurs post partum in rats, mice and guinea-pigs. The GL formed, in the absence of mating and conception, become the cL of lactation; those of rats and mice are somewhat prolonged compared to the GL of the oestrous cycle, but the cL of the guinea-pig are not dissimilar (Perry \& Rowlands, 1962). In the hamster, no post partum ovulation occurs and all follicles with antra become atretic at this time. No antral follicles develop so long as suckling remains, whereas an increase in interstitial tissue occurs (Greenwald, 1965). In lactating rats and mice there is a prolonged dioestrus (Long \& Evans, 1922; Parkes, 1926) which is, in rats, at least partly due to suckling (McKeown \& Zuckerman, 1938). There is a general correlation between the number of young suckled and the length of the dioestrous period and gestation (Enzmann, Saphir \& Pincus, 1932; Weichert, 1940; Bruce, 1961). Administration of oestrogen enables implantation to take place at the normal time (Weichert, 1942; Whitten, 1955). In rabbits, receptivity declines markedly during the first 10 days of lactation after which anoestrus sets in (Hammond, 1925). In the field vole, $M$. agrestis, on the other hand, no spontaneous ovulation occurred post partum and the cL of pregnancy degenerated at a faster rate than those of mice (Greenwald, 1958). Graafian follicles were present throughout the lactation period although they appeared slightly reduced in size at mid-lactation; no increase in interstitial tissue was detected. The smears were only rarely dioestrous and no marked lengthening of gestation occurred. There was no anoestrous period, ovulation could be induced by mating at any time during lactation.

Evidence of reduced FSH and/or LH release due to suckling has been produced for mice, rats and hamsters (Sadler \& Browning, 1961; Rothchild, 1960; Greenwald, 1965; Minaguchi \& Meites, 1967). In marked contrast to these species, suckling in the vole appears to have little effect on gonadotrophic secretion although the smaller Graafian follicles may indicate a slight reduction of FSH secretion. Oestrogen secretion probably occurs in the vole during suckling, as indicated by oestrous behaviour and vaginal smears. Suckling does not appear to inhibit the release of ovulatory-inducing hormone as ovulation follows coitus. It is possible that the suggested release of oestrogen during lactation 
explains the lack of marked delay in implantation and hence lengthening of gestation.

The vole is a species that is well known for its population cycles. Numbers build up rapidly for 3 or 4 years and then a dramatic decline takes place (Chitty, 1952). If female voles in the wild have a similar reproductive physiology to those in this laboratory stock then the fact that they are induced ovulators, that they remain receptive throughout lactation and have no marked delay in implantation could perhaps explain the rapid expansion of population that takes place periodically.

\section{ACKNOWLEDGMENTS}

I should especially like to thank Dr J. R. Clarke for his encouragement and for supervision of the work. Also I would like to thank Dr F. H. G. Marriott for statistical advice, Miss Judith Tompkins for technical assistance, and Dr F. V. Clulow for criticizing the manuscript.

This work was carried out during the tenure of a Postgraduate Studentship from the Ministry of Agriculture, Fisheries and Food.

\section{REFERENCES}

Asdels, S. A. (1964) Patterns of mammalian reproduction, 2nd edn. Cornell University Press, Ithaca. Austin, C. R. (1957) Oestrus and ovulation in the field vole (Microtus agrestis). F. Endocr. 15, iv.

BaIley, V. (1924) Breeding, feeding, and other life habits of meadow mice (Microtus). F. agric. Res. 27, 523.

Brambell, F. W. R. \& Hall, K. (1939) Reproduction of the field vole Microtus agrestis hirtus Bellamy. Proc. zool. Soc. Lond. A, 109, 133.

BREed, W. G. (1967) Ovulation in the Genus Microtus. Nature, Lond. 214, 826.

BRUGE, H. M. (1961) Observations on the suckling stimulus and lactation in the rat. F. Reprod. Fert. $2,17$.

ChrrTy, D. (1952) Mortality among voles (Microtus agrestis) at Lake Vyrnwy, Montgomeryshire in 1936-9. Phil. Trans. R. Soc. B, 236, 505.

ChrrTy, H. (1957) The oestrous cycle and gestation period in the lactating field vole, Microtus agrestis. F. Endocr. 15, 279.

ClaARK, F. H. (1936) The oestrous cycle of the deer mouse Peromyscus maniculatus. Contr. Lab. vertebr. Genet. $1,1$.

Clarke, J. R. \& Kennedy, J. P. (1967) Effect of light and temperature upon gonad activity in the vole (Microtus agrestis). Gen. comp. Endocr. 8, 474.

Cowan, I. McT. \& ARsenault, M. G. (1954) Reproduction and growth in the creeping vole Microtus oregoni, Serpens Merian. Can. F. Zool. 32, 198.

Enzmann, E. V., Saphir, N. R. \& Pincus, G. (1932) Delayed pregnancy in mice. Anat. Rec. 54, 325.

Greenwald, G. S. (1956) The reproductive cycle of the field mouse, Microtus californicus. F. Mammal. 37, 213.

GreEnwald, G. S. (1957) Reproduction in a coastal Californian population of the field mouse, Microtus californicus. Univ. Calif. Publs Zool. 54, 421.

Greenwald, G. S. (1958) A histological study of the reproductive tract of the lactating mouse. $\mathcal{F}$. Endocr. 17, 17.

Greenwald, G. S. (1965) Histological transformation of the ovary of the lactating hamster. Endocrinology, 77, 641 .

Hamilton, W. J., JR (1941) Reproduction of the field mouse, Microtus pennsylvanicus (Ord.) Mem. Cornell Univ. agric. Exp. Stn. 237, 1.

HAMmOND, J. (1925) Reproduction in the rabbit. Oliver \& Boyd, Edinburgh.

Lestre, F. H. \& Ranson, R. M. (1940) The mortality, fertility and rate of natural increase of the vole (Microtus agrestis) as observed in the laboratory. F. Anim. Ecol. 9, 27.

Long, G. E. \& Evans, H. M. (1922) The oestrous cycle in the rat and its associated phenomena. Mem. Univ. Calif. 6, 1 . 
MaKeown, T. \& Zuckerman, S. (1938) The suppression of oestrus in the rat during pregnancy and lactation. Proc. R. Soc. B, 124, 464.

Minagughi, H. \& Mertes, J. (1967) Effect of suckling on hypothalamic L.H. releasing factor and prolactin inhibiting factor and pituitary L.H. and prolactin. Endocrinology, 80, 603.

Papanicolaou, G. N. (1954) The atlas of exfoliative cytology. Harvard University Press, Cambridge, Mass.

Parkes, A. S. (1926) Observations of the oestrous cycle of the albino mouse. Proc. R. Soc. B, $100,151$.

Perry, J. S. \& Rowlands, I. W. (1962) The ovarian cycle in vertebrates. In: The Ovary, Vol. 1, Chap. 5. Ed. S. Zuckerman. Academic Press, New York.

Ranson, R. M. (1934) The field vole (Microtus) as a laboratory animal. 7. Anim. Ecol. 3, 70.

Rothchil, I. (1960) The corpus luteum-pituitary relationships. The association between the cause of luteotrophin secretion and the cause of follicular quiescence during lactation; the basis for a tentative theory of the corpus luteum-pituitary relationship in the rat. Endocrinology, 67, 9.

Sadler, W. A. \& Browning, H. G. (1961) Gonadotrophic secretion in lactating mice. Proc. Soc. exp. Biol. Med. 106, 558.

SELYE, R. M. (1928) Microtus californicus in captivity. F. Mammal. 9, 43.

Weichert, C. K. (1940) The experimental shortening of delayed pregnancy in the albino rat. Anat. Rec. 77, 31.

Weichert, G. K. (1942) The experimental control of prolonged pregnancy in the lactating rat by means of oestrogen. Anat. Rec. 83, 1.

Whitren, W. K. (1955) Endocrine studies on delayed implantation in lactating mice. 7. Endocr. $13,1$. 